\title{
INTERNATIONAL JUSTICE VS PUBLIC OPINION? The ICC and Ethnic Polarisation in the 2013 Kenyan Election
}

\author{
Thomas P Wolf \\ Dr Thomas P Wolf is Public Affairs Research Analyst for IPSOS-Synovate, \\ Nairobi, Kenya ${ }^{1}$ \\ email: twolf@wananchi.com
}

\begin{abstract}
This article examines a perennial factor in Kenyan politics, that of communal identity, and how it was mobilised in the context of the March 2013 elections. Using survey data it tracks attitudes regarding a unique feature of these elections: the (still-expected, if bitterly challenged) International Criminal Court (ICC) cases of Uhuru Kenyatta and William Ruto, of the Kikuyu and Kalenjin communities, respectively, for their alleged roles in the widespread violence that followed the disputed 2007 election. Remarkably, notwithstanding this ethnic divide at the time, their 'defendant' status provided, first, the personal, and subsequently, the communal foundation for their political union and ultimate triumph over then prime minister Raila Odinga, becoming Kenya's new president and deputy-president, respectively. In exploring this success, the paper uses nationally-random survey data which also reveal the degree to which Kenyans became increasingly polarised as the elections drew nearer. In addition, qualitative material from media coverage and personal interviews suggests just how such polarisation occurred. The conclusion raises several questions about the way various possible scenarios involving the ICC issue could yet reconfigure the ethnic alliances evidenced in this recent and controversial election, and about the salience of ethnic identity in Kenya's electoral politics more generally.
\end{abstract}

\section{INTRODUCTION: ETHNIC IDENTITY VS ISSUE POLITICS?}

A rumour that Eldoret North MP William Ruto was to be appointed internal security minister circulated in Mt Kenya at the height of March 2008 coalition-Cabinet negotiations between President Mwai Kibaki and Prime Minister Raila Odinga unsettled many residents.

1 The views expressed in this paper are those of Dr Wolf, and not of IPSOS-Synovate. 
Amid the hostility between the Kikuyu and Kalenjin, some Mt Kenya residents could not reconcile themselves to the idea of Ruto as the minister in charge of police. Many Central Kenya residents whose relatives had been killed during the 2007 / 8 violence in the Rift Valley were hostile to Ruto, in whose constituency the Kiambaa church massacre occurred.

On Sunday thousands of them will flock to Nakuru Afraha Stadium - the same venue that for months hosted victims of the post-election violence - to rally support for a pre-election coalition deal involving Mr Ruto as Mr Uhuru Kenyatta's running mate in the next elections.

Sunday Nation 2 December 2012

... Three sure things happen at the polls every five years - people are killed, Kenyans vote along tribal lines, and the same crooks are returned to power ...

Why do Kenyans allow themselves to be manipulated by elites with whom they've nothing in common? Why is the average voter so gullible and easily tricked and bamboozled with the predictable tribal card?

Mutua 2012

Notwithstanding the considerable 'democratic gains' that have been made with regard to African elections since the onset of the 'Second Liberation' in the early 1990 s - starting, in most countries, with the end of one-party or military political monopolies - there remain significant deficits in their conduct (Essoungou 2011). Indeed, the recent introduction of 'hi-tech' instruments, supposedly aimed at reducing the opportunities for 'rigging', have had, at best, a very chequered impact (Wrong 2013). Critical, of course, are the perceived 'stakes' involved in the competition for power in such countries, and especially for incumbents, who - having had the benefits of rule without well-entrenched rule-of-law regimes must often contemplate exits from office with considerable trepidation (Southall \& Melber 2006).

Despite these flaws, or rather, to the extent that such failings do not obscure actual voting patterns, the study of such elections also encompasses the more mainstream topics of research and analysis: political party formation and function, campaign strategies, and - at the end of it all - voter behaviour.

In this context, a 'typical' African election is often said to be little more than an 'ethnic census', where voters line up behind candidates with whom they identify on that basis, at least at the national level, where contests between 
major candidates of the same ethnic group are less likely to occur (Posner 2005; Nnoli 1998). ${ }^{2}$ Or, to put it another way, 'identity politics typically trump ideology' (Van de Walle 2006, p 84), even if the way in which such communal identities are expressed tends to reflect the particular electoral systems that structure the competition for power (Bogaards 2006).

Ethnicity, clearly exacerbated by the country's 'first-past-the-post' system, has long been recognised in Kenya as the most salient factor in how political support is organised. Criticism of this fact is often coupled with a lament about the general absence of more 'rational' issue-based choices. Writing in the aftermath of the bitter (and violently) divisive 2007 contest, for example, Oloo (2010, p 56) argued that:

Ethnic groups are mobilized around ethnic leaders, whether in mono parties, coalitions or pacts. The ultimate goal is to either capture the presidency for the ethnic community or belong to a power sharing formula that caters for particular communities.

For their part, with the same (2007 election) context in mind, Kanyinga, Okello \& Akech (2010, pp 24-5) were more critical in addressing this issue, while setting it within broader, structural parameters:

[E]thnicity and how it is expressed in Kenya's electoral politics is the toxic waste from a political economy of inequality, centralized state power and a majoritarian electoral system' [while] 'political elites appropriate political discourses for personal gain' [as they] turn to ethnicity ... to advance their personal interests.

At the same time, any substantial treatment of ethnicity as an explanatory variable must begin with a recognition of its twin aspects: purely emotive factors that generate non-material, psychological rewards (and suffering), and contrasting instrumental ones, where 'belonging' itself is perceived as a means to access tangible 'goods' (or to avoid losses of a similar nature). ${ }^{3}$

Yet however persistent ethnic identity has been in Kenyan political life, the 4 March 2013 election was a substantial break with the past. While such identity was certainly again subject to elite 'appropriation', this occurred in an atmosphere that was highly issue-based, and over an extended period of time.

2 The Kenyan contest of 2002 was an exception in this regard, when both major candidates, Mwai Kibaki and Uhuru Kenyatta, were from the same (Kikuyu) community.

3 The interplay of the two in historical terms, though with greater emphasis on the latter, is explored from the (mainly) Luo and Kikuyu perspectives in Kenya by Atieno-Odhiambo (2004) and Muigai (2004), respectively. 
Also entirely novel, the central issue - the judicial fate of those 'most responsible' for the violence that followed the 2007 election - took on a profound international dimension: the forthcoming trials of Uhuru Kenyatta, then one of two deputy prime ministers, and William Ruto, MP and formerly a Cabinet minister, at the International Criminal Court (ICC) in The Hague.

Stemming from the failure of the political class to establish a domestic judicial process by which those most responsible for that post-election violence (PEV), which nearly tore the country apart (Human Rights Watch 2008), could be held accountable, this agenda was subsequently 'globalised' by Kenya's 'domestication' of the Rome Statute of 1998 that created the ICC and led to its subsequent intervention there (ICG 2012; Brown \& Sriram 2012; Arieff, Browne, Rhoda \& Weed 2011).

Contrary to widespread expectations both within Kenya and elsewhere, however, these two prominent political figures - among the six initially named by the ICC's chief prosecutor as suspects, and subsequently as among the four defendants confirmed for full trial - were able to use their international 'criminalindictee' status for two remarkably successful purposes. First, they overcame stubborn resistance within their respective inner circles and wider communities to forge, initially, a de facto and ultimately, a formal electoral ('Jubilee') alliance, built mainly on the foundation of Kenyatta's The National Alliance (TNA) and Ruto's United Republican Party (URP).

Secondly, they chipped away at and eventually erased an apparently unbridgeable lead enjoyed by their main rival, Prime Minister Raila Odinga, emerging triumphant against him and his Coalition for Reform and Democracy (CORD) running-mate, then vice-president Kalonzo Musyoka, ${ }^{4}$ if only by a highly contentious ' whisker'. ${ }^{5}$ In doing so, they largely transformed their status from that of 'suspects'-' perpetrators' into that of maligned 'victims', primarily of foreign 'forces', with whom their domestic political opponents were allegedly aligned.

But the foundation for such success is the country's ethnic demography, of which two facts are most relevant: ${ }^{6}$ no single ethnic group could aspire to obtaining the $50 \%+1$ votes the new Constitution requires to achieve a first-round

4 CORD was the product of his own Orange Democratic Movement (ODM) and Musyoka's ODMWipe, among others.

5 The full official results may be found at: docs.google.com/spreadsheet $/ \mathrm{ccc}$ ?key=0AtBHjBYCnlE FdFJtbTU0RDdfUkhZWWxfbmNrUURpN3c\# gid=1. Kegoro (2013a; 2013b) reviews the IEBC's technological failures, while Sharma (2013a) documents key anomalies in the (several) voters' registers, and separately critiques the 'passing grade' given to the election by several international election observation groups (2013b). The Odinga petition is available at: www.kenya-today. $\mathrm{com} /$ facing-justice/ raila-odinga-cord-election-petition; that filed by the African Centre for Open Governance (AFRICOG) is available at: www.africog.org/category / election-petition.

6 It should be noted that these groups vary significantly in terms of their degree of cultural and economic homogeneity in both historical and contemporary terms. 
presidential vote victory, ${ }^{7}$ and the five-largest (Kikuyu, Luhya, Kalenjin, Luo, Kamba) comprise nearly three-quarters of the population, so that, in terms of selecting both a presidential and a deputy-presidential running-mate candidate, it makes little sense to go outside these main groups in terms of a viable presidential ticket, other things being equal.

In addition, members of only two of these groups, the Kikuyu and Kalenjin, each associated with a quite distinctive governance style reflecting a particular (if changing) constellation of cross-ethnic alliances, have occupied the presidency. Consequently, many Kenyans have quite specific perceptions of the implications of having a future leader from either of them at the apogee of state power, notwithstanding the unfolding uncertainties of the impact of the country's new Constitution.

\section{ORIGINS OF THE ICC CASES AND ODINGA'S EVAPORATING POLL LEAD}

The emerging cracks in the alliance between Ruto and Deputy Prime Minister Uhuru Kenyatta may be a blessing for Raila because there is a growing feeling within the Rift Valley region that the community might just have to do with Raila in 2012 because they will not be comfortable backing another presidential aspirant from Central Kenya. ${ }^{8}$

Majority of our people are yet to clearly decide how they will vote in 2012. But with Kibaki as outgoing President it will be difficult to sell another Central Kenya candidate in this region. If Raila will be in a run-off against someone from Central then the PM stands a good chance to attract the Rift Valley votes,' said Engineer Tom Murgor.

The Star 4 June 2011

The next election will be very different from all those that came before. It will be Kenya's first single-issue election. The one wedge issue that will divide the politicians and by extension the electorate will be this: What is the candidate's position on International Criminal Court (CC) action and will the candidate, if elected into office, cooperate with or block the handing over of the Ocampo Six to face international justice? ... Mr Odinga will ... seek to win the support of the two thirds

\footnotetext{
7 It also requires obtaining a minimum of $25 \%$ of the vote in at least half of the country's 47 counties, which both the main candidates in this 2013 election achieved.

8 Kalenjin constitute some $40 \%$ of the population of this region; Kikuyu are its next largest group, about $25 \%$.
} 
of Kenyans that opinion polls say back trials at The Hague, as he seeks to build a cross-ethnic alliance that might help him ascent [sic] to the presidency.

The Nairobi Law Monthly April 2011, pp 51-52

... [T] he bedrock support for Mr Uhuru Kenyatta's TNA frowns upon an alliance with Mr Ruto. Similarly, the DNA of Mr Ruto's URP is against TNA. But Mr Ruto's supporters have a clear message for their man: please take us into power or to power. They are also telling $\mathrm{Mr}$ Ruto that he does not have to be president in 2013.

Opanga 2012

The 9 March official announcement of the election results by the Independent Election and Boundaries Commission (IEBC), gave Kenyatta a first-round victory by the slimmest of margins (notwithstanding obtaining some 800000 more votes than Odinga - a figure also challenged in his election petition): $50.5 \%$, based on a vote-margin of 62907 out of some 12220000 valid votes (excluding the 'rejected ballots'), or only $50.07 \%$ - a margin of only 8449 votes - if the rejected ballots are included in the calculation (which the Supreme Court ruled should not have been the case). Between them, the other six candidates received just under $6 \%$ of all votes ( $2 \%$ less than all the final polls had indicated). ${ }^{9}$

One of the factors that fed suspicions about the IEBC's declaration was that not one of the last set of four voter-intention polls conducted some two weeks before the election put either Kenyatta or Odinga within 5\% of the 50\% mark, though IPSOS-Synovate's did give the former the narrowest of leads (and within the survey's margin-of-error), as shown in Figure 1 (Wikipedia 2013. ${ }^{10}$

Based on the IEBC's figures, the main factor that accounted for this major 'discrepancy' between the polls and the official results - aside from the gains accruing to the visibly more effective Jubilee campaign (Sunday Standard 12 May 2013; Muluka 2013) - was differential voter turnout in the stronghold areas of the two main competitors, predicted by IPSOS's research analyst a week before the election (Wolf 2013). ${ }^{11}$ This largely reflects the fact that, as was revealed by

9 Maina (2013c) provides a highly critical initial appraisal of the Supreme Court's procedural and evidentiary reasons for upholding the declared result. Africa Confidential (2013) recently raised serious questions about Kenyatta's overall victory margin.

10 Earlier surveys generally used samples of 2000 , which entail an error-margin of $+/-2.2 \%$. For subgroups of the sample for this and earlier survey results, such error-margins are correspondingly larger. In all cases, the confidence-level is $95 \%$.

11 This, indeed, turned out to be the case (again, discounting claims of serious irregularities, noted above). IPSOS-Synovate (2013c) interrogated the official results in these terms in a media presentation released on 15 March and found a 6\% turnout advantage for Kenyatta in 15 of his largest 'vote-basket' areas, compared to that of Odinga. Likewise, Kenyatta won a larger share of the vote in Odinga's strongholds than vice-versa. 
Figure 1

Expressed presidential/deputy president voting intentions (February 2013)
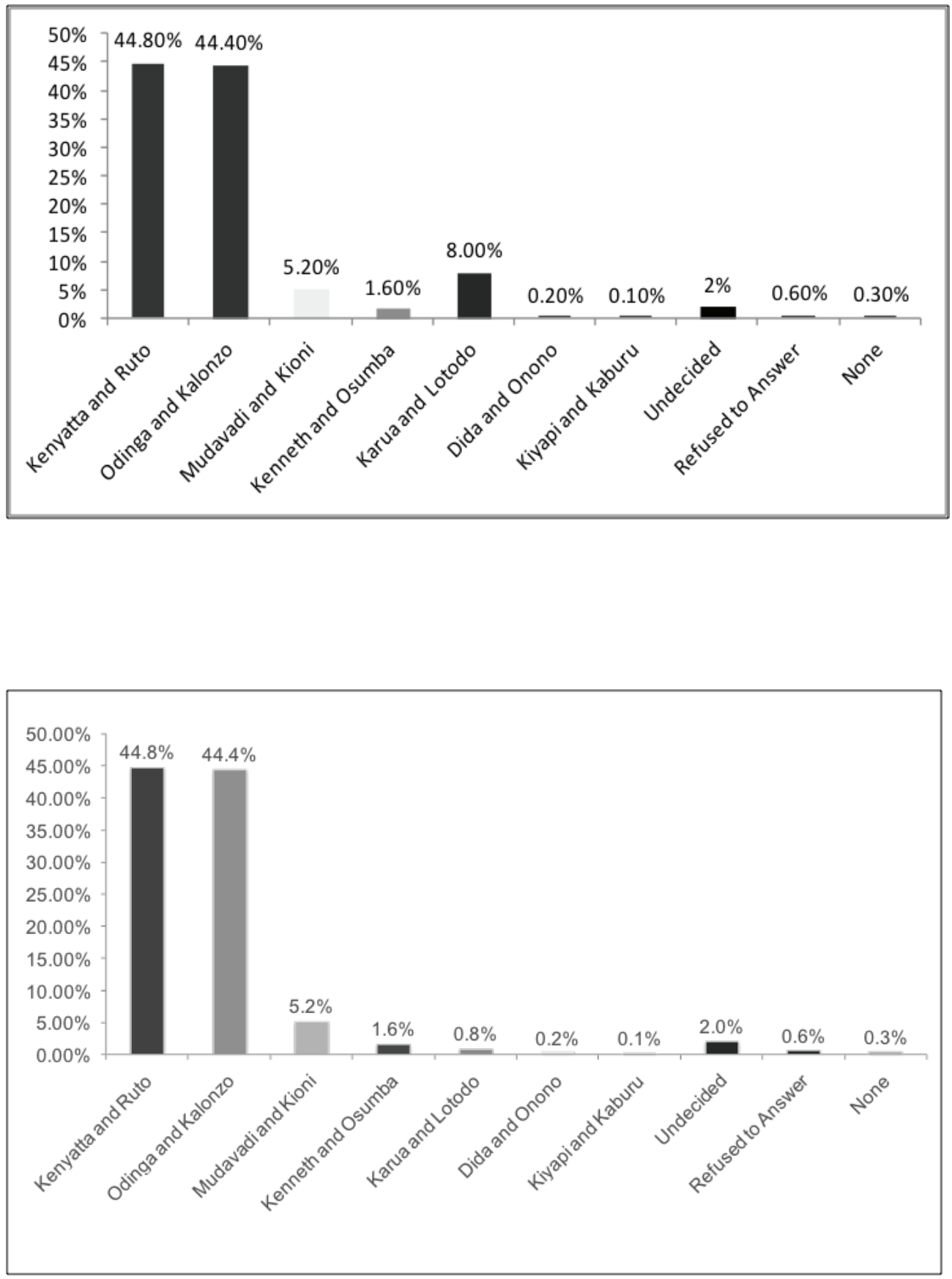

Source: IPSOS-Synovate 2013a 
data from the same February IPSOS poll, while more than three-quarters of those prepared to vote for Jubilee were from the combined Mt Kenya-Kalenjin communities, as represented by the two candidates at the top of their ticket, fewer than half of CORD's intended voters were from communities represented by Odinga and Musyoka - the Luo and Kamba - notwithstanding their statistical tie in the polls (as shown in Figure 1). Given the salience of ethnicity in motivating voters, therefore, the latter alliance would have needed a considerably greater turnout effort to make up for this inherent gap. ${ }^{12}$

Yet in view of the antagonism in recent Kalenjin-Kikuyu relations it was the very emergence of this alliance that was so unexpected. Here it was the ethnic dynamics associated with the ICC cases which accounts for this, eventually allowing Jubilee to contemplate a first-round victory.

These dynamics stemmed from the violent crisis - leaving more than 1000 dead and at least 500000 displaced - that followed the abrupt announcement of incumbent President Mwai Kibaki as the 2007 election winner over then opposition leader Raila Odinga, and his furtive swearing-in ceremony immediately thereafter (Human Rights Watch 2008; Miguna 2012, especially 'In the Trenches', pp 199-262; Mueller 2008; Branch \& Cheeseman 2009). To resolve it, a Grand Coalition Government was established, by which power was shared between them (Mwagiru 2008; Lindenmayer \& Kaye 2009).

Together with the National Accord and Reconciliation Act (2008) that created this fractious but ultimately durable arrangement, the Kenya National Dialogue and Reconciliation agreement mandated various reforms aimed at preventing any such future crisis. These included the establishment of the Commission of Inquiry into the Post-Election Violence ('Waki Commission'), whose commissioners submitted their report in October 2008.

Among the commission's recommendations was that the Kenyan government create a Special Tribunal to investigate and prosecute those ' most responsible' for the crimes that had been committed. Failing this, such responsibility would be transferred to the ICC, which had become part of the Kenyan judiciary through Parliament's ratification of the Rome Statute in 2005 and promulgation of the International Crimes Act in 2008, itself a product of this crisis-resolution effort (International Commission of Jurists-Kenya 2010, p 8).

12 Specifically, Kenyatta's 'Mt Kenya' communities (Kikuyu, Embu, Meru, Mbeere, Tharaka) comprise about $30 \%$ of the country's population and Ruto's Kalenjin 13\%. By contrast, CORD's Luo and Kamba comprise only about $12 \%$ and $11 \%$ respectively. Such a calculation assumes uniform voting within these communities, an issue which generated heated pre-election debate (ictville.com 2013; Maina 2013a; 2013b). 
In the event, three attempts by Parliament, the first of them on 6 February 2009, to enact the required legislation for this purpose failed, thus opening the doorway to the ICC's intervention. ${ }^{13}$ This began with the African Union's chief mediator during the National Accord negotiations, retired UN Secretary-General Kofi Annan, handing over a confidential list of 21 individuals to the ICC's Chief Prosecutor, Luis Moreno-Ocampo, on 9 July 2009. The latter then used his prerogative on 26 November 2009 to seek permission from the Pre-Trial Chamber to open an investigation, which was granted on 31 March 2010, and he arrived in Kenya shortly thereafter, on 8 May, to do this.

Based on his investigations ${ }^{14}$ he constructed two cases, each with three suspects, whose identities were announced on 15 December 2010. In addition to Kenyatta, these were Francis Muthaura, secretary to the Cabinet/head of civil service, and Hussein Ali, the commissioner of Police (members of the Meru and Somali ethnic groups, respectively).

Whatever the evidentiary basis for his choices, however, achieving a 'political balance' also appeared to be critical. Thus, one case involved the 'first phase' of the PEV, from late December 2007, in which pro-ODM Kalenjin 'warrior-youth' were the aggressors and certain vulnerable Kikuyu residents of the Rift Valley the victims. The other case stemmed from the 'retaliation attacks' on members of pro-ODM ethnic groups (mainly more logistically accessible Luo and Luhya), also in the Rift Valley, by a pro-Party of National Unity (PNU) Kikuyu youth militia, at the end of January 2008.

But if achieving such a balance was the chief prosecutor's intention, he erred, as the political realities on the ground had shifted considerably by the time of his announcement. Specifically, among the three Kalenjin suspects in the first case, only one, Henry Kosgey, MP for Tinderet, Industrialisation minister and ODM party chairman, remained close to Odinga, as Ruto, initially minister of agriculture, had, by mid-2009, 'migrated' to the Kibaki / PNU side of the partisan divide, taking with him most ODM Kalenjin MPs. ${ }^{15}$

This Odinga-Ruto split is central to the scenario that subsequently unfolded.

13 Brown and Sriram (2012, p 253) explain the contrasting - if complementary - reasons why it proved impossible to obtain the required two-thirds majority for this proposal. Ironically, in retrospect, it was Ruto, Kenyatta, and their parliamentary allies who led the resistance to such a local tribunal and instead supported The Hague option (with the refrain, 'Don't be vague, go to Hague'). For an example of Ruto's position, see: www.kenya-today.com/opinion/william-ruto-for-icc-trials.

14 In addition to the Waki Report (which generated the 21 names in the 'Waki envelope'), his efforts also reportedly relied on investigations conducted by the Kenya National Commission of Human Rights (2008).

15 The third suspect on the ODM side, vernacular radio journalist/ presenter Joshua arap Sang (accused of propagating hate-speech that led others to commit human rights crimes), while a strong Ruto supporter, held no formal political position. 
While various other issues contributed to it, ${ }^{16}$ at its heart lay the potential criminal cases that emanated from the Waki Report, which went beyond Ruto as an individual to the wider Kalenjin community. As a local analyst pointed out shortly after Parliament's first unsuccessful attempt to establish a special tribunal:

So far, power tussles and partisan interests among Kenya's power elite have frustrated efforts to establish the special tribunal, which was voted out [sic] in parliament. Some leaders whose names have been mentioned in the report have raised questions relating to the integrity of Justice Waki, who was suspended as a judge in 2003 on corruption allegations and only reinstated on a technicality, and by extension the integrity of the entire report. For instance, Rift Valley parliamentarians have cited high level lobbying and bribery as the reasons 'why [the report] has clearly avoided implicating Raila in even one riot in Kibera'... The report has not only created splits within and between the parties to the National Accord, [but also] its chances of ending a condition of impunity have become slimmer by the day.

Kagwanja 2009, p 383

Two key issues were involved here. One was police treatment of Kalenjin youths involved in the PEV, many of whom were allegedly tortured and 'disappeared' (Daily Nation 15 August 2009). Although Odinga had sought to defend these youths early in 2008 during the African Union-led mediation process (while he continued to call for the prosecution of those responsible for 'bungling' the election) (Daily Nation 15 August 2009), he fell silent on this issue almost immediately after becoming prime minister, suggesting to many Kalenjin that he no longer cared about their fate.

The other issue was Odinga's repeated backing for the investigation and prosecution of those responsible for the PEV as the 'only way to end impunity', while publicly ignoring the fact that his / the ODM's share of power was largely a

16 Relevant here were the contrasting political careers of the two leaders, especially Ruto's origin as a Moi youth-winger in 1992 while Odinga was a long-term Moi-era detainee; his support for Kenyatta's first presidential bid in 2002 (when Odinga backed Kibaki), and his association with Musyoka during the latter's struggle with Odinga for the ODM nomination in 2007. More recent issues include: Ruto's resentment that Musalia Mudavadi rather than he became the ODM's deputy; his defence of the Mau Forest'squatters' that government policy - most forcefully articulated by Odinga - aimed at removing/ relocating after 2008; the opposition of Ruto's ODM faction to the Odinga-backed new Constitution prior to the 2010 referendum and Ruto's patronage-competition with Odinga during his tenure as minister of agriculture (Muluka 2011; The Star 16 February 2013). 
product of it. ${ }^{17}$ Moreover, given that Kosgey was among the few Kalenjin leaders who remained aligned to him, such calls made Odinga appear even more disloyal than did his treatment of the now-'wayward' Ruto. Such was the case, for example, when Odinga repeatedly disassociated his ODM side of the Grand Coalition Government from the 'shuttle diplomacy' efforts of then vice-president Musyoka to gain support from African governments and the UN Security Council to have the cases returned to the Kenyan judiciary, which had come to be viewed as a much 'safer' option once the ICC process materialised (Daily Nation 26 January 2011; The Standard 19 February, 2011). The same applied to MPs from his region, whose identical position was assumed to reflect their leader's wishes. ${ }^{18}$ Such considerations were thus reflected in the 'partisan interests' and the 'splits within and between the parties' noted above, exemplified by the accusations by 'Rift Valley parliamentarians' [that is, Kalenjin] that 'high level lobbying and bribery' had allowed Odinga himself to escape the very 'accountability' measures that he was championing.

Such bitterness among the Ruto ODM faction about the immunity Odinga appeared to enjoy was underscored in one of the periodic reports of the consultants employed by the Kofi Annan Foundation to monitor the country's reform process. In particular, they noted how the pre-trial hearings in September-October 2011

... have deepened fissures within the coalition government ... [T] have introduced new perspectives about levels of culpability of the suspects and reinforced the view that the list of suspects [compiled] by the ICC was 'incomplete' because it does not comprise leaders from some of the ethnic communities. These discourses have continued to imbue the investigation with political undertones, which overshadow debate about the question of impunity. In effect, focus on 'who else should be investigated' obscures the question of why investigations are taking place and reinforces notions of victimisation for political ends.

South Consulting 2011, p 48

17 This stemmed in part from the fact that it proved impossible to revisit the actual ballot count or vote tally, leaving the 'real' winner of the election to (largely partisan) speculation. Thus, even if the ODM leadership always distanced itself from the PEV (as opposed to the 'mass action' protests it repeatedly encouraged) (www.youtube.com/watch?v=WUeuRd94MIw), it was clear to everyone that without it, the Kibaki side could never have been cajoled / forced - mainly by Western actors, in concert with the AU mediation team - into conceding even a minimal share of real power (see, eg, Mwagiru 2008, pp 82-86, 135-136).

18 For example, as was reported early in 2011: 'During the parliamentary debate on whether Kenya should bail out of the ICC, a pattern that emerged was that of Nyanza politicians being pro-ICC while everyone else appeared to be sceptical about the path the process has taken' (TOPIX 23 April 2011). 
But there was also significant 'motion' on the PNU/Mt Kenya side of the political-communal divide: consolidation of the community's 'moral defence' of key leaders purportedly involved in the 'retaliatory violence' phase that had generated the second case. Here, however, the issue was less a reaction against any leader or group of leaders perceived as having gained political mileage from it (as was clearly the case with regard to the Ruto-ODM faction) than a rejection of the 'justice' agenda itself. Such a development was described by Mghanga (2010, p 87) just as the reality of the ICC's entry into Kenya's judicial space began to sink into the public's consciousness towards the end of 2009:

... [M]any people do not really condemn the 2007-2008 post-election violence with sincerity ... I have heard some people saying openly that the violence would not have stopped, had some leaders not organised, armed and sponsored their youth to attack members of other ethnic groups in Naivasha, in order to avenge the violence that was targetting [sic] their own group in the Rift Valley and elsewhere ...

So deep [sic] entrenched is the problem of negative ethnicity that people, including some MPs and top politicians, whose names are likely contained in Justice Waki's envelope for prosecution either in Kenya or at The Hague, are considered as heroes by a considerable number of members of their ethnic groups, mostly for participating in these horrendous acts. After all, that is why they still hold leadership positions.

Figure $2^{*}$

\section{Support for potential/actual (main) presidential candidates: 2009-2013**}

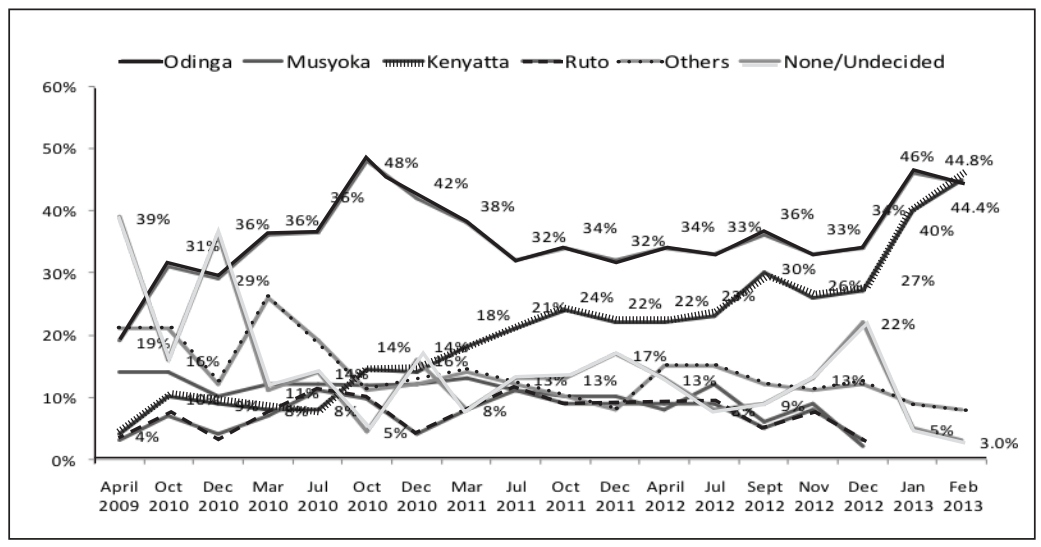

Source: IPSOS Synovate 2013a

* For reasons of visual clarity, percentages are only shown for the top two candidates, their eventual running-mates, and those still undecided

** The verbatim question, through the end of 2012, was: 'If the next election were held now, aside from President Kibaki, who would you vote for, if that person was a candidate?' For the last two (2013) polls the question was: 'Which pair of presidential and deputy-presidential candidates do you intend to vote for?' 
In sum, then, by the time the 'Ocampo Six' were named, the country's political - and moral - terrain had already undergone a major reconfiguration, and one that over time Odinga's main rivals in the forthcoming election put to extremely effective use, enabling them to whittle away at his long-standing lead in the opinion polls.

That this was achieved, ultimately putting Kenyatta/Ruto at least within 'striking distance' of the 'magic' 50\% mark, is shown in Figure 2, which presents expressed presidential voting intentions among Kenyans of voting age over the previous two years: ${ }^{19}$

Two additional fortuitous factors related to the unfolding ICC and electoral calendars had an impact on these poll results and on the election itself. First, a High Court judgement on 17 March 2012 pushed the election date from December to March 2013. ${ }^{20}$ While this change gave all participants more time for election preparations it was more beneficial to Ruto and Kenyatta, both of whom had first to create new political vehicles (URP and TNA, launched on 15 January and 20 May 2012 respectively), and then work out the vote- and expected parliamentary seat-sharing strategies and agreements that their Jubilee alliance, launched in November, necessitated.

Secondly, in July 2012, following numerous procedural delays engineered by the defence teams, the ICC set the Kenyan cases for April 2013, dashing the Odinga campaign's hopes that his main rivals' mandatory court appearances would remove them - at least geographically - from the race (Daily Nation 9 July 2012).

Yet it still required a leap of the imagination for many that a leader of the 'victim' community that had suffered so much death, destruction and displacement could unite with the top leader of the community whose warrioryouths had wreaked that violence upon them, whether for an electoral or any other purpose. Writing in 2010, for example, Lynch (2011, pp 211-212), who has had long research experience in the Rift Valley, captured the lingering cleavage between the Kikuyu and the Kalenjin, who, according to her interview respondent,

19 Note here that only in the last two polls were deputy presidential running mates known, whereas prior to that all these individuals (among about a dozen others) had 'marketed' themselves as presidential contenders, and that following completion of the one-month voter registration exercise on 18 December the samples for the January and February polls were allocated according to its figures (which gave Kenyatta/Ruto an estimated 'boost' of 2-3\% due to higher proportions in their strongholds), as opposed to the official census. Further, regarding this second point, nearly $97 \%$ of those selected for interviews claimed to be registered voters, when only 13.4-million of some 22-million eligible adults were, suggesting that more than one-third of all such respondents lied. Such a proportion is similar to that found in Kenyan surveys related to previous elections and constitutional referenda, both prior to and after those events, though it does not appear that such 'lying' biased the results in one direction rather than another.

20 The new Constitution sets the election date as the second Tuesday in August of every fifth year, but the High Court ruled in January 2012 that Parliament should serve out its full five-year term, which began in March 2008. 
'physically beat us, burned down our houses, and killed our friends and relatives'. She then added, ominously:

More worrying still is evidence of a proliferation of small arms and a pervasive sense that people should be prepared for the worst. As one Kikuyu of the troubled Molo area surmised, 'If it happens again, it will be much worse ... People are prepared to fight, so there'll be resistance ... and as election day approaches, people will continue buying [weapons].'21

In the same vein, as late as February 2011, a member of Odinga's parliamentary 'inner circle' could claim that 'the Kikuyu have no real political interest in Ruto; they are only using him to allow for the re-settlement of their displaced people in the Rift Valley' (Personal Interview, Nairobi, 18 February 2011).

Yet such an assertion appears somewhat disingenuous given the active efforts Odinga and his aides were making at the time to win back Kalenjin support, using councils of elders from both the latter and his own community to do so, however dim were the realistic prospects of success. As was pointed out at the time: 'A major grievance for the Kalenjin elders is the ODM letter to the ICC reinforcing the case against the Ocampo Six and stating they should be tried at The Hague and not locally' (The Star 4 June 2011).

Yet for most observers - including especially, perhaps, those committed to an accountability agenda - the political-electoral potential of this budding 'political romance of the accused' was easy to underestimate. Thus, while alluding to it, the appraisal of Brown \& Sriram (2012, p 257) was, in retrospect, unrealistically sanguine:

Even though the various attempts to establish a special tribunal have failed, the debates have fed demand for accountability and have unwittingly provided a great civic education programme among Kenyans on the ICC and other justice mechanisms. In 2011, when asked their preferred means to deal with the alleged perpetrators, 61 percent of the 2000 Kenyans polled chose trials at the ICC, compared with 24 percent for a hybrid tribunal and only 8 percent for the regular courts. Still, a sizeable number of individuals can be mobilized in opposition to ICC involvement. When Ruto and Kenyatta returned to Nairobi in April 2011, after their initial hearings in The Hague,

21 Indeed, this author points out that she was still hearing comments of this nature in December 2012 (Personal Interview, Nairobi, 3 June 2013). 
they were given a public heroes' welcome. Accused of crimes against humanity and other serious charges, they have cast themselves as political victims of national and international plots against them and retain a significant public support in their own ethno-regional communities.

In this connection, a more detailed consideration of such survey results over time, incorporating ethno-political dimensions as well, suggests how such ICC indictee status offered a lifeline, if not necessarily to acquittal, at least to votes.

\section{GETTING INSIDE THE 'JUSTICE’ vs 'POLITICAL OPPORTUNITY’ NUMBERS}

Homegrown justice systems and instruments had failed. Kenyans had turned their eyes to the international community and especially to one man, called Luis Moreno-Ocampo.

[M]ake no mistake: Moreno-Ocampo is bringing his tool kit to Kenya. Masters of impunity beware! Moreno-Ocampo is not a small boy ... Kenyans have waited for justice for far too long

Muluka 2010

... [O]ur definition of justice is not always what lawyers describe on the basis of fact and evidence. That is also why often we shift the goalposts, to realign with our tribal radar.

Tanui 2011

The great majority of Kenyans (more than eighty per cent) support the ICC process as the most credible method to fighting [sic] the culture of impunity in Kenya. Surveys by leading institutions in the country have repeatedly confirmed this position. ${ }^{22}$

Orange Democratic Movement 2011

Two seemingly contradictory messages emerged from a recent survey of public opinion in Kenya. The first is that Kenyans overwhelmingly support the International Criminal Court (ICC) at The Hague, where

22 As shown in Figure 3, at the beginning of March 2011, when the ODM issued this document, the figures produced by 'leading institutions in the country' were actually about $20 \%$ lower than the figure quoted here. 
the alleged ringleaders of the violence that followed the country's disputed election in 2007 are due to be tried next year. The second is that in the presidential elections scheduled for March, the majority of voters intend to support either a candidate who is among those the ICC has indicted, or one who plans to save them from being put in the dock at The Hague.

The Economist 10 October $2012^{23}$

Support for the ICC process for the country as a whole, covering the entire period from the time of the ICC's entrance up to the election, was remarkably stable, as shown in Figure 3. Still, a few shifts of note occurred.

Figure 3

Support for ICC Trials (Showing Key Events) Oct 2010 - Feb 2013

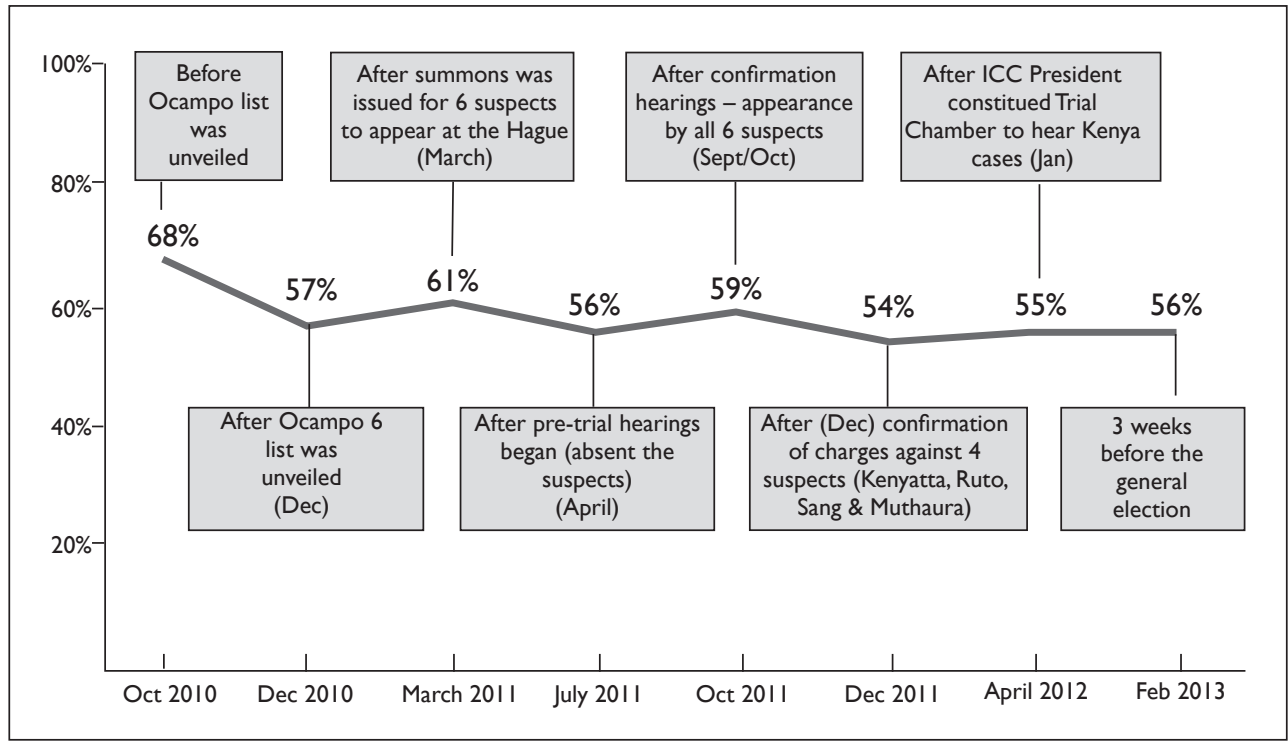

Source: IPSOS-Synovate survey data, October 2010-February 2013

The largest one is the first: an 11\% drop in support for the ICC process (from $68 \%$ to 57\%) just after the six initial suspects were named at the end of 2010, apparently making the country's formal commitment to the Rome Statute all too real for some Kenyans. Subsequently, after rising by 4\% (to 61\%) in March 2011, it fell by $5 \%$ by July (to $56 \%$ ) following the pre-trial hearings, which, again,

23 It is unclear on what basis The Economist concluded that Odinga was indeed committed to 'saving' them. 
seemed to increase the possibility of forthcoming trials. But support rose by 3\% following the confirmation hearings in September-October 2011, perhaps due to the procedural fairness exhibited by the ICC officials and the impressive performance by the accused and their legal teams, inspiring confidence that even if the trials went forward the chances of acquittal were high. Next, it fell by $5 \%$ (to $54 \%$ ) in December of that year, following a succession of prayer-peace rallies led by Kenyatta and Ruto, starting with their first massive one, held at the main public stadium in Eldoret, the epicentre of the 2008 violence, almost immediately after their return from The Hague, where the charges were confirmed (The Standard 28 January 2012).

Only minor fluctuations occurred thereafter, with a clear, if very modest, majority continuing to support the process through the immediate pre-election period (56\% in February, 2013).

However, such statistical stability in national terms occludes significant ethnic group variations, as shown in Figure $4 .{ }^{24}$ While attitudes among members of these larger communities diverged only modestly at the beginning of this period -aside from the Kalenjin, whose level of support for the ICC process was $28 \%$ lower than the next least supportive group, the Mt Kenya cluster, at 57\% - the gaps between the 'defendant' and other communities widened immediately thereafter (from April 2011), though narrowing somewhat by late October. Coming just after the confirmation-of-charges hearings (when, in national terms, support for the ICC increased by $3 \%$, as noted above), optimism within the defendants' Mt Kenya and Kalenjin communities regarding their legal teams' capacity to protect the defendants from the ICC's threatened 'tsunami' appears to have been buoyed (if only temporarily), more than compensating for the drop in support expressed by the Luo, Luhya and Coastals, in particular. Thereafter (as from December of that year) the gap widened again, and dramatically so, as the election approached.

Another stable gap in support for the ICC also stands out: that between the Mt Kenya community and the Kalenjin, averaging nearly 20\% over the December 2010-April 2012 period, which narrowed only on the eve of the election in February 2013, to just 6\% (based on a 6\% drop among the Mt Kenya community and a 9\% upswing by the Kalenjin).

Several factors could account for it. One was the widespread belief that the case against Ruto, given his association with 'aggressive' violence (among other factors), was stronger in both moral and evidentiary terms from the outset, thus putting him in greater danger than Kenyatta.

24 Kenyan survey firms refrain from releasing results with such ethnic group correlations, though there is no legal restriction on doing so. 


\section{Figure 4}

\section{Main Ethnic Groups' Support for the ICC's Involvement (December 2010-February 2013) ${ }^{25}$}

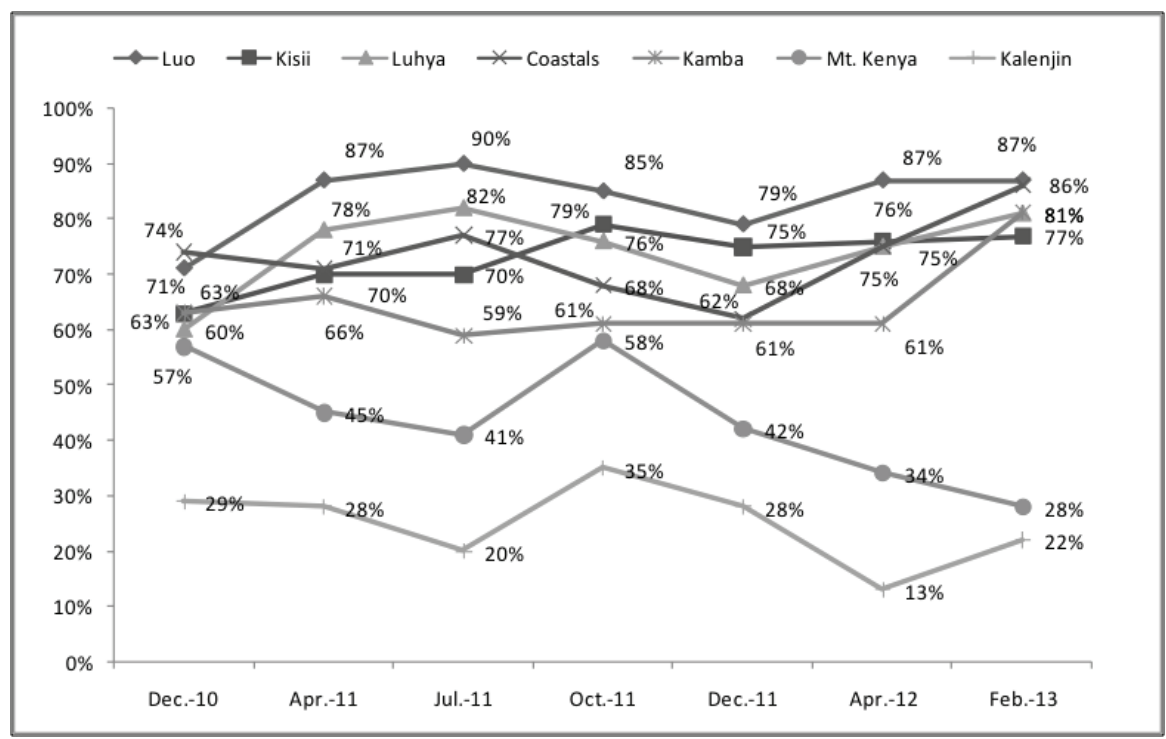

Source: IPSOS-Synovate surveys December 2010-February 2013

Also, in contrast to Ruto, having a fellow-Kikuyu in State House (Kibaki), and a coaccused (Muthaura) known as a long-time Kibaki confidant, may have suggested to some a higher level of state protection for Kenyatta. Further, given the moral approval that many attached to his alleged 'crimes' (associated, as they were, with 'defending' the community), 'his' people may have found it more difficult to imagine that any 'fair' judicial process could actually result in a conviction. Finally, in political terms, the absence of any other remotely viable alternative Kalenjin presidential (or even deputy presidential running mate) candidate may also have contributed to a higher level of anxiety about the ICC threat among members of Ruto's own community over this period.

It is notable, though, that at no time did Kalenjin support for the ICC process approach zero, with more than one in five supporting it from the outset, aside from the April, 2012 survey results, though it regained most of this 'lost ground'

25 In five of these surveys, the question was a preference-choice between the ICC, a local tribunal, or forgiveness-amnesty (December 2010, April 2011, July 2011, October 2011 and February 2013), while in the other two it was simply one of being 'happy' or 'unhappy' with the ICC's involvement (December 2011, April 2012). These surveys used one of two types of sampling methodology: household / face-toface (April 2011, July 2011 Oct. 2011, December 2011, April 2012 and February 2013; and mobile phone interviews (December 2010). 
in the final pre-election poll. ${ }^{26}$ However modest, this 'late hour' upswing could reflect the fact that a Kenyatta presidency held the promise of a reduction (if not the elimination) of the ICC threat for Ruto, especially given Jubilee's steadily rising poll numbers - and their repeated claims of confidence in a first-round victory. ${ }^{27}$

A similar contrast is seen in another finding from the July 2011 survey (a full six months after the 'Ocampo-6' were named): nearly three times as many Kalenjin as Mt Kenya respondents ( $30 \%$ vs $12 \%$ ) preferred the 'cases-dismissedwith-amnesty' option, even if the latter figure still far exceeds that for each of the main ethnic supporters of the Odinga side of the political divide: the Luo (3\%), Luhya and Kamba communities (4\% each).

Altogether the survey results suggest that notwithstanding the ICC prosecutors' repeated assertions that their task was 'a criminal investigation and not a political analysis' (see, eg, Reuters 12 May 2010), and that the 'accountability targets' were 'individuals rather than communities' (The Standard 26 October 2012), the Court's involvement was perceived in highly partisan-communal terms throughout this period, just as the PEV itself had been.

\section{MOVING TOWARDS THE FINISH LINE: THE WEST'S ICC 'GODSEND'}

If Uhuru wins, the ICC will just disappear, but if Raila wins he'll be sure to arrest both Uhuru and Ruto ...

The ICC is a tool of the West, used just to oppress Africa. Why not charge President Bush and those other Western leaders instead of only targeting Africans?

Personal Interview, Limuru, 4 March 2013

26 Examination of such demographic variables as age, religion, education level and income did not reveal any basis for this contrast, but sub-ethnic identities were not captured. Significant here, however, is the fact that among Mt Kenya/Kalenjin respondents who reported that they were not intending to vote for Jubilee, $33 \%$ cited the encumbrance of the ICC trials as the main reason; next most frequently cited was an association with corruption, by only $8 \%$, while $29 \%$ declined to answer the question (IPSOSSynovate 2013a). Yet based on the official results, this disinclination to vote for Jubilee weakened somewhat as election day approached.

27 This was seen, for example, in Mukurwe-ini MP Kabando wa Kabando's boast that Jubilee would win with 55\%, notwithstanding all the opinion polls to the contrary (K-24 News 23 January 2013). It should also be noted that Kenyatta and Ruto did not announce their joint candidacy until 19 October. Earlier, in August, Musyoka claimed that he and Ruto had agreed on a joint ticket (Sunday Standard 19 August 2012) and just a week before the Kenyatta-Ruto announcement Odinga had attempted to strike a similar deal with the latter (Daily Nation 12 October 2012). 
President Obama clearly stated that the choice of who will lead Kenya is up to the Kenyan people, but it is also important to note that choices have consequences. We live in an interconnected world and people should be thoughtful about the impact that their choices have on their nation and on the world.

Carson February 2013

It was a Godsend! I mean, here were foreign powers dictating to Kenyans on how to vote. We were shocked that a junior officer [sic] in the US government could contradict his boss. It also made Raila look like a project of Western powers and we loved it. Jubilee went into overdrive.

Sunday Standard 26 May 2013

Throughout 2012, when it was still assumed that the elections would take place during that year, attention to - and tensions over - the ICC issue increased due to a combination of the approaching election and the progress of the cases themselves. As indicated in Figure 3, on 23 January charges were confirmed against four of the six original suspects, including Kenyatta and Ruto. (The cases against Kosgey and Ali were dropped on the grounds of insufficient evidence; the 'numerical balance' in the original ODM-PNU distribution of cases remained, however.) A mobile-phone poll conducted the following week revealed that fewer than half of all respondents (48\% and $47 \%$, respectively) felt that Kenyatta and Ruto remained legitimate presidential contenders. Just over two months later these figures had slipped to $44 \%$ and $42 \%$ (with $49 \%$ and $51 \%$ holding the view that they should retire from politics until they were cleared and $7 \%$ having no opinion (IPSOS-Synovate Poll Release 1 May 2012)). Yet, as shown in Figure 2, expressed presidential voting intentions in this period (the 12 months from October 2011) were nearly constant, with Odinga getting about a third of such expressed support, and Kenyatta around a quarter.

The results of the April 2012 poll - just under a year before the election reflect this pattern, with Odinga leading Kenyatta by $12 \%$ (34\% to 22\%), with 9\% expressing support for Musyoka and 8\% backing Ruto (and 10\% 'undecided'). Combining these still-hypothetical choices gives Odinga / Musyoka a 13\% 'lead' over Kenyatta/ Ruto (43\%-30\%) (IPSOS-Synovate SPEC Barometer 1 May 2012). The remainder was divided among the several minor candidates. Significantly, this gap also reflected the fact that within Kenyatta's own Central Province only $72 \%$ affirmed their support for his candidacy 'now that the charges against him at the ICC have been confirmed'. But while such figures seemed to have bolstered 
the Odinga campaign's confidence, they also indicated that a first-round victory for him was highly unlikely.

Such a conclusion is reinforced by the results of another question included in this survey: 'Who would you vote for if neither Kenyatta nor Ruto were candidates?' Ominously for Odinga, this scenario gave him no measurable gain, as most of the ICC defendants' survey votes were 'inherited' by three other potential candidates, first among them being Musyoka, who thereby gained 10\% (from 9\% to 19\%). (The other main 'beneficiaries' were Mudavadi - up 5\% to 10\% and Martha Karua - to 9\% from 5\% - with most of the balance accruing to the 'undecided' category.) This was partly a consequence of his numerous 'shuttle diplomacy' visits on their behalf (noted above) and his earlier close association with both Kenyatta and Ruto in the so-called 'KKK' (Kikuyu, Kalenjin, Kamba) alliance (Daily Nation 24 January 2011). This, along with the general role he had played as Kibaki's dutiful (and largely 'anti-Odinga') vice-president since the last election, meant that many of the ICC defendants' supporters apparently viewed him as a 'safe' alternative in the event that their candidates could not stand. As late as December, shortly before he joined Odinga as his running-mate, Musyoka revealed that Kenyatta and Ruto had agreed to support his presidential candidacy but had subsequently 'betrayed' him (The Star 3 December 2013, pp 1, 6).

During this entire period, however, while the two ICC suspects continued to pursue their individual presidential ambitions, their often in-tandem public appearances underscored their associated judicial and electoral fates, even if Ruto was always the junior partner. ${ }^{28}$ Moreover, as the election approached, hopes among Odinga's backers for a presidential contest absent the ICC indictees slowly evaporated, as their trial dates were repeatedly pushed back (as noted above), and several local challenges to their candidacies based on the integrity-requirement provisions of the new constitution were dismissed by both the judiciary and the IEBC..$^{29}$

Towards the end of 2012, however, CORD's fading hopes were nearly reversed by a new scenario: that Kenyatta would pull out of the race in favour of Mudavadi, who had formally broken ranks with Odinga on 2 May of that year

28 Beyond Ruto's smaller home-ethnic base (and hence, lower poll numbers), certain personal negatives (such as several corruption cases still in court) and several other factors fed into this understanding, including: Kenyatta's earlier presidential bid in 2002 (for which Ruto was an enthusiastic campaigner), a close association with key members of the incumbent Kibaki regime, and his family's apparently limitless wealth. (In 2011, Forbes magazine ranked him the 26th-richest individual in Africa.)

29 On 15 February 2013 the High Court rejected the petition filed by a local NGO with this objective (Kenya Law Reports 19 March 2013). Earlier, the IEBC had claimed that only it had the authority to determine this issue, and only after nomination papers had been filed, but when the Jubilee team did so, on 30 January, no objections were raised. 
(having alleged a democracy 'deficit' within $\mathrm{ODM}^{30}$ ) in order to campaign for the presidency on his own (Kenya Daily Post 6 December 2012). Given his minimal poll ratings at the time, even in his own Western region, as compared to Odinga's, as well as the presence of several 'minor' Kikuyu candidates in the race, who might help split Kenyatta's 'orphaned' votes, this prospect was welcomed by the CORD campaign.

Two factors had encouraged Kenyatta to contemplate this exit option. One was the perception among some senior State House officials that there were simply not enough Kenyans prepared to support the succession of one Kikuyu president by another. The other was the increasing anxiety among senior figures within the business community (many of them Kikuyu) about the likely impact of damaging sanctions should Jubilee win (Daily Nation 16 December 2012). But the 'deal' collapsed within a week of its crafting (The Star 18 December 2012; The County Weekly 7-13 January 2013), ${ }^{31}$ leaving the Kenyatta-Ruto pair in mid-December to finalise their campaign strategy, under the eye-catching banner of 'UhuRuto'.

The responses to several other questions about the (possible) ICC trials included in IPSOS-Synoate's final pre-election survey shed additional light on how this issue was influencing the dynamics of the campaign during its final phase..$^{32}$ They reveal a nearly even split (49\% vs 46\%) between support for Hague - as compared to Kenya-based - trials, assuming they were to proceed. At the same time, as shown in Figure 5, whereas 56\% wanted them to proceed in any location (as also shown in Figure 3), 39\% preferred that they be 'dismissed with amnesty.' By comparison, two years earlier only 3\% supported this latter option, an indication of how much the issue had been politicised (IPSOS-Synovate SPEC Barometer Release 15 April 2011).

30 Having been Odinga's de facto running-mate in 2007 , it was generally assumed he would again assume that role until this startling announcement.

31 Several hypotheses were offered as to why the deal collapsed, the most convincing being Kenyatta's failure to overcome the resistance among members / candidates in his own party who were dependent on his ethno-partisan coattails to win. Eventually taking nearly two-thirds of the vote in Mudavadi's home region, it appears that Odinga was the main beneficiary of this deal-gone-bad, however, since it made the former look gullible and weak - and Kenyatta duplicitous - at least to many of Mudavadi's fellow Luhya.

32 By this time, just over $93 \%$ of all respondents could name at least one of the four remaining defendants (with $90 \%$ and $87 \%$ being aware of Kenyatta and Ruto, respectively). The comparable figures obtained in an IPSOS-Synovate survey conducted within a week of the naming of the 'Ocampo-6' in December 2010 were $81 \%$ and $86 \%$. Only respondents who could name at least one of the four defendants were asked these ICC-related questions. 


\section{Figure 5}

ICC Options: By Total, Main Presidential Candidates' Supporters

\begin{tabular}{|l|l|l|l|}
\hline 'The ICC cases should ...' & $\begin{array}{l}\text { Total } \\
(\mathbf{n}=\mathbf{5} 5 \mathbf{5 0})\end{array}$ & $\begin{array}{l}\text { Odinga/ } \\
\text { Musyoka } \\
(\mathbf{n = 2} \mathbf{4 3 7})\end{array}$ & $\begin{array}{l}\text { Kenyatta/Ruto } \\
(\mathbf{n = 2 5 6 8 )}\end{array}$ \\
\hline ... go forward & $56 \%$ & $84 \%$ & $26 \%$ \\
\hline ... be dismissed with amnesty & $39 \%$ & $12 \%$ & $68 \%$ \\
\hline Not Sure & $3 \%$ & $2 \%$ & $3 \%$ \\
\hline RTA & $2 \%$ & $2 \%$ & $3 \%$ \\
\hline
\end{tabular}

Source: IPSOS-Synovate SPEC Survey February 2013

But the impact of this issue on the campaign is even more evident when these results are correlated with supporters of the main candidates. Among CORD's, it was more than three times greater than among supporters of their Jubilee-indictee rivals ( $84 \%$ vs $26 \%$ ), even if just over a quarter of the latters' supporters also favoured this option, suggesting that such a yearning for accountability had not been entirely extinguished, even among those prepared to vote for them. Though two other factors may also have been involved here: a conviction that either or both defendants would emerge unscathed after their trials - thus enhancing their status - and a realisation that at this stage such a 'dismissed-with-amnesty' option no longer existed.

Nevertheless, had these indicative figures held through to election day, Jubilee might well have failed even to approach a first-round victory. Instead, an attempt by 'Westerners', apparently aimed at influencing the Kenyan electorate, backfired, providing the Jubilee campaign with a 'godsend' that it was able to exploit adroitly.

Such 'neo-colonial' claims had been part of the anti-ICC narrative well before the formal emergence of the Jubilee alliance. Early in 2012, for example, visiting British Foreign Minister William Hague (his surname being perhaps an unfortunate coincidence) echoed numerous past statements by resident and visiting Western officials when he called for 'justice for the post-election violence victims' and 'an end to impunity'.

This triggered a swift rejoinder from Kenyatta and a group of aligned MPs that the ICC cases were 'part of a foreign scheme to influence the outcome of elections' (Sunday Standard 5 February 2012). Yet despite Odinga's vehement denial (Daily Nation 8 February 2012), ${ }^{33}$ Ruto repeated the allegation shortly afterwards,

33 In his denial, Odinga reminded his critics that he had supported the establishment of a special tribunal to hear all the major post-election violence cases, but that this had been rejected by those closest to Kenyatta and Ruto (Daily Nation 6 February 2012). 
describing the instigation of the cases as part of a (Western) 'plot' to install a more pliant individual in office (Daily Nation 7 March 2012). He took the same stand in response to similar comments by visiting US Secretary of State Hillary Clinton the following August (Daily Nation, 7 August, 2012).

Claims by such figures as British MP Ian Paisley in March that Britain and other 'foreign governments' were indeed using the ICC to 'clear the way for Prime Minister Raila Odinga to ascend to power' only served to strengthen such perceptions (Daily Nation 20 March 2012).

It was at this time that several anti-Odinga MPs sought to 'document' such interference (though the documentation was later described as fraudulent by a parliamentary Select Committee), as one local analyst reminded his readers early in 2013, and which highlighted how Odinga and his supporters unwittingly bolstered the very claims that were being made against them:

The Prime Minister often plays into the hands of the two suspects who have often attacked him in public. The height of it was in March [2012] while responding to claims in Parliament from MPs allied to Mr Kenyatta and Mr Ruto who tabled suspicious documents alleging that the British government was working with the ICC to have President Kibaki indicted over the violence after he leaves office. ${ }^{34}$ The office of the Prime Minister released a scathing statement on the suspects. ${ }^{35}$

'Crimes against humanity are worse than murder. Yet these suspects of crimes against humanity remain free to traverse the country holding "prayer meetings" while Kenyan suspects of the lesser crime of murder conduct their prayers only behind the forbidding walls of Kimiti Maximum Security Prison, often for years before their cases are heard,' said a statement from the Raila Odinga Secretariat. 'The guilt or innocence of suspected perpetrators is proved through trial, where the facts of the case are examined. No one becomes innocent through public grand-standing and shouting from rooftops "I am innocent".'

From this, the two, who have packaged themselves as victims of persecution by power [sic] foreign forces who are intent on killing their political dreams, got the ammunition needed to paint Odinga

34 An investigation by Parliament's Defense and Foreign Relations committee eventually determined the documents were fake (The Star 14 December 2012).

35 Raila Odinga Secretariat 12 March 2012. As the secretariat put it: 'It is clear that the present posturing against the ICC, complete with weaving in of the PM's name and that of the British Government, is a dress rehearsal for non-cooperation with the ICC. It is clear that the foundation is being laid for the accused to refuse to attend trials of the cases against them.'

The Standard 28 March 2012 
as working with these forces. They roped in their communities, effectively alienating the PM from their regions

Wanjala 2013, p 42

This is not to say that Odinga and his allies were entirely consistent on this matter, occasionally questioning the moral logic of this 'accountability' process themselves. Such was the case during Ocampo's first visit to Kenya, in May 2010, when Odinga suggested that those responsible for mishandling the 2007 election should also be subjected to ICC scrutiny, and early in 2012, when Odinga's wife released a 'personal statement' advocating that the cases be 'handled here in Kenya', while expressing sympathy for the defendants' families (Weekly Citizen 13-19 December 2010; Daily Nation 27 January 2012).

Nevertheless, it was the 'interference' on the eve of the election itself that appears to have had the greatest impact. This began with Kofi Annan, who, during one of his reform progress update visits to Kenya, in October, made it clear to Kenyans that a Kenyatta or Ruto government 'would have grand implications, which everyone needs to ponder', a message he repeated two months later in a BBC interview (The Standard 21 October 2012; BBC 4 December 2012). Moreover, given that this second 'message' came just as negotiations between Kenyatta and Mudavadi had reached their most sensitive stage, it may be asked whether Annan was aware of this situation and, if so, had hoped to influence its outcome.

Next, British High Commissioner Christian Turner, during a Rift Valley tour in January, 2013, remarked to journalists that while 'Kenyans are free to elect the leaders they want', the British government does not have contact with ICC indictees 'unless it is essential' (The Standard 16 January 2013).

Evidently in response, a few days later Kenyatta told an Al Jazeera interviewer that he believed it was Kibaki and Odinga who should be on trial at The Hague since they, not he, had been electoral adversaries in 2007, while recalling that when he was declared the loser in the 2002 contest he quickly conceded defeat (Daily Nation 24 January 2013).

However, this issue only became a Jubilee campaign centrepiece after US President Barack Obama's video message to Kenyans on 5 February 2013. In it, he emphasised the need for a 'free and fair' election, while adding that '[ $t$ ]he choice of who will lead Kenya is up to the Kenyan people' (Obama 5 February 2013). Since he made no mention of the ICC cases, it appeared that Obama's main concern was that the election be peaceful, given American/Western security interests in the region, yet the remark was immediately clasped by the Jubilee candidates, who proclaimed at subsequently rallies that it 'should send a clear message' that 'Kenyans have the right to elect a leader of their choice', and thus 
their rivals 'should now change tack and engage us on issues and not on the basis of sanctions or the ICC' (The Standard 7 February 2013).

But this message was evidently not entirely the one that Obama had intended to convey. Thus, his out-going Assistant Secretary of State for African Affairs (and former ambassador to Kenya), Johnnie Carson, quickly arranged a teleconference with Kenyan journalists to insist that such election choices 'have consequences', even if he mentioned no names (Carson February 2013), a position immediately echoed by the French and Swiss envoys, who underscored their own governments' commitment to upholding the Rome Statute in terms identical to those used earlier by the British High Commissioner (Daily Nation 8 February 2013).

For their part, CORD leaders, seeing this confrontation as an electoral opportunity, encouraged the public to consider the practicality of running the government from abroad, while warning of the economic damage that such 'consequences' would entail. FORD-Kenya leader and former foreign minister, Moses Wetang'ula, ${ }^{36}$ told a CORD rally a few days later:

You must know what the international community says about this country. We must watch carefully because we can't dismiss what they say as malice. We cannot afford to be isolated by our partners.

The Standard 11 February 2013

But such statements were, likewise, grist for the Jubilee mill, as 'defending Kenya's sovereignty' - with Odinga linked to those assaulting it (Hard Talk Kenya 4 March 2012). ${ }^{37}$ This was so despite the fact that Ruto's trial was then set to begin on the very day of a possible second round (10 April), and Kenyatta's on the next, forcing Kenyatta on occasion to downplay the issue, ${ }^{38}$ while giving CORD hope that such a calendar coincidence would help drive home the point to both Jubilee and the remaining (if few) 'undecided' voters that theirs was, in the end, a lost cause.

Several additional findings from IPSOS-Synovate's final pre-election survey suggest how Kenyans' views on these issues largely reflected their partisan alignment. Two-thirds (66\%) of Odinga's/Musyoka's supporters agreed that

36 Along with Musyoka, he had been among the most intransigent PNU leaders during the 2008 postelection crisis, demanding that Odinga/ODM 'go to court' if they had any complaints about Kibaki's highly irregular victory (Miguna $2011 \mathrm{p} 217$ ).

37 The fact that Odinga had reportedly offered to 'push' the ICC for the cases to be brought to Kenya during his futile attempt to woo Ruto back to his side nearly a year before the election lent additional credence to this claim (even if others close to Odinga denied that he had made any such promise) (The Star 5 May 2012.

38 For example, in falsely stating during a campaign meeting with the Visa Oshwal (Hindu) business community in Nairobi at the end of January that their cases would not run concurrently (Daily Nation 31 January 2013) and in asserting in the second presidential debate that his ICC responsibilities were just a 'personal matter'. 
'representatives of foreign governments should tell Kenyans how their relations with foreign countries will be affected if the ICC indictees are elected', whereas exactly the same proportion of Kenyatta's/Ruto's supporters opposed such pronouncements. Regarding the perceived damaging economic 'consequences' resulting from a Jubilee win, only $9 \%$ of CORD supporters thought this unlikely, compared with $48 \%$ of their Jubilee counterparts, even if nearly as many of the latter $(41 \%)$ foresaw either major or moderate negative effects following a Kenyatta-Ruto victory. ${ }^{39}$

It may thus be concluded that Western interference had the opposite effect of its intention - helping Jubilee both to mobilise its existing support base more energetically and to win over a limited but critical number of additional voters. As Africa Confidential (7 June 2013) put it:

On balance, the cases helped the indictees: some electors said they wouldn't vote for Kenyatta and Ruto because of the charges but many more said they would, as a way of asserting national sovereignty ...

Actual constituency-level election results confirmed such 'hero'-status, revealing a level of ethnic polarisation even greater than that of the final polls. Voters in the Mt Kenya region gave the Jubilee presidential ticket over $95 \%$ of their vote, with Kalenjin areas of the Rift Valley doing likewise at just a slightly lower level (about 92\%). (These figures compare with about 99\% of the vote for CORD among Odinga's fellow Luo, though falling to about $85 \%$ among Musyoka's Kamba community.) Evidently more voters than not took to heart Kenyatta's assertion that a vote for Jubilee was 'a vote of no-confidence in the ICC' (Daily Nation 31 January 2013), as he became the first such indictee to be elected head of state.

\section{CONCLUSION}

'The I.C.C. was definitely a factor in this election, but not necessarily the factor you would expect,' said Maina Kiai, a prominent Kenyan human rights defender. 'It got people out. People were saying, "They're our boys, they're our sons, we need to protect them."'

New York Times 7 March 2013

[Jubilee is best described as] a strange beast, consisting of two such different parts that had been thought to exist only in fantasy

Waweru 2012

39 Indeed, the fact that nearly half of Jubilee supporters expected that such damage would occur suggests just how steadfast was their commitment to 'UhuRuto'. 
Going into this election two related questions occupied particular attention: who will win (whether in the first or second round) and what will be the winner's position with regard to the ICC cases. Whatever doubts remain - and whatever future (if unofficial) investigations reveal - about whether Jubilee did, in fact, get more than the mandatory $50 \%+1$ threshold, ${ }^{40}$ it is now the second question that has riveted national and international, attention.

Notwithstanding the African Union's / Heads of State conference's controversial decision at the end of May 2013 to seek 'referral' of the Kenyan cases to some regional or national judicial institution (Daily Nation 27 May 2013; Kipkorir 2013), it is unclear how this could be done, based on the court's legal procedures, and the UN Security Council's repeated refusal to intervene, most recently in declining to respond to Kenya's Permanent Representative to the UN, who sought to have the charges dropped altogether (Daily Nation 9 May 2013; The East African 25-31 May 2013, pp 8-9; Daily Nation 27 May 2013). ${ }^{41}$ Thus, even with the recent postponement of their trial dates, first to 9 July and then to 12 November for Kenyatta (The Star 20 June 2013) and to 10 September for Ruto and Sang (Daily Nation 3 June 2013), ${ }^{42}$ and notwithstanding the request by the defendants' lawyers that their courtroom appearances take place via video link,${ }^{43}$ it remains likely that both trials will eventually go ahead, even if the case against the president is said to be the weaker of the two.

In this regard, myriad scenarios are possible. One, if perhaps the most unlikely, is that, despite their protestations to the contrary, either or both of them will fail to appear in The Hague when their trials begin. This could trigger the issue of warrants for their arrest. But since these could not be effected nationally (or now, presumably, regionally), both the president and his deputy would become fugitives from justice, in turn triggering certain (if unknown) 'consequences' from Kenya's most important development partners (aside from China).

Another scenario would unfold if they do attend their trials at the stipulated times. In that case, however, because of their expected lengthy - and overlapping - duration, the president and his deputy could face major challenges in attempting to perform at least some of their official duties from abroad (Mue 2013).

40 Africa Confidential (21 June 2013) recently raised serious questions about the official IEBC result.

41 Note, however, Kenyatta's reaffirmation of his commitment to co-operate with the ICC in a post-election BBC interview (Daily Nation 14 May 2013).

42 They also recommended that certain formal sessions of the trial be held in Kenya or Tanzania (Arusha), but this must be affirmed by two-thirds of the 16 ICC judges. Local human rights groups have protested, however, saying any hearings in the region would lead to the further intimidation - and attrition - of witnesses; indeed, it was this issue that led the ICC to drop the Muthaura case (Reuters / AFP 4 June 2013).

43 While the Trial Chamber subsequently ruled that Ruto will be allowed to be absent during 'some sessions' of his trial, it rejected the video-link proposal (Daily Nation 18 June 2013). 
Neither of these scenarios, however, is likely to undermine the ethnic coalition that underpinned their electoral victory and which now provides a solid working majority in both houses of Parliament and the basis for ongoing executive branch appointments. Nor would one in which the ICC 'blinks' and both cases are terminated (Wrong 2013).

But it could be severely tested in a situation where Kenyatta's case is dropped while Ruto's goes to full trial. And the same could occur if both trials go forward, but only one results in a conviction.

The political impact of such varied possibilities underscores the pragmatically fluid nature of ethnic mobilisation and alliances in Kenya generally, and in this election in particular. As Mutua, (2013), a US-based Kenyan analyst (and an openly bitter critic of the winners) could conclude in the wake of Jubilee's triumph:

If the International Criminal Court is right, the two funded death squads to kill, maim, and loot each other's folks. Mr Ruto only subordinated himself to Mr Kenyatta because he couldn't win on his own. Nor did he have good options after falling out with ODM's Raila Odinga. Only a victorious partnership with Mr Kenyatta - a fellow ICC indictee - could possibly save the pair from The Hague. It was a strategic alliance.

Indeed, the newly sworn-in deputy-president made the same point in his impromptu remarks during the inaugural ceremony on 9 April, 2013:

In 2002, many people did not believe it was possible for people from Nyanza [ie, the Luo] to vote for Kibaki, [yet] they voted almost to a man for him. In 2007, many people did not believe Rift Valley [ie, the Kalenjin] would vote for Raila Odinga, [yet] they did it almost to a man. In 2013, many people did not believe that Kalenjins would vote for Uhuru [a Kikuyu, yet] they indeed voted [for him] almost to a man. ${ }^{44}$

As the survey data presented above have suggested, the dramatic rise and success of the 'UhuRuto' campaign is best understood as a conflation of a numerically robust ethnic alliance with a national-'sovereignty' agenda and one which, in order even to approach an overall electoral majority, needed to submerge the initial 'accountability' agenda of justice for the PEV victims of 2008.

44 In this context Ruto evidently did not deem relevant the fact that Kenyatta had won a majority of votes in all Kalenjin-dominated constituencies in the 2002 election. 
In the circumstances, even if this election was unique in the unprecedented 'international' nature of a major part of the campaign's content - and indeed, that a substantive issue assumed such prominence - both voter registration and voting patterns underscore the reality of (near-unanimous) solidarity in such ethnic terms, even for most voters from outside the communities of the presidential candidates themselves. Whether this 'novelty-within-continuity' was simply a one-off 'fluke' that opens the door to a more durable issue-oriented basis for electoral competition, or, rather, constitutes nothing more than old ethnic 'wine' in a new international-issue 'bottle', remains to be seen.

\section{REFERENCES}

Africa Confidential 54(12), 7 June 2013.

Africa Confidential 54(13). 2013. 'The Long, Long Vote Count', 21 June.

Arieff, A, M Browne, M A Rhoda \& M C Weed. 2011. International Criminal Court Cases in Africa: Status and Policy Issues. Washington, DC: Congressional Research Service.

Atieno-Odhiambo, E S. 2004. 'Hegemonic Strategies \& Instrumentalities of Survival: Ethnicity and Democracy in Kenya'. In B Berman, D Eyoh \& W Kymlicka (eds). Ethnicity \& Democracy in Africa. London: James Currey.

BBC. 2012. 'Kofi Annan urges Kenyans not to vote for indicted politician', 4 December.

Bogaards, M. 2007. 'Electoral Systems, Party Systems, and Ethnicity in Africa'. In M Basedau, G Erdmann \& A Mehler (eds). 2007. Votes, Money and Violence: Political Parties and Elections in Sub-Saharan Africa. Scottsville: University of KwaZulu-Natal Press.

Branch, D \& N Cheeseman. 2009. 'Democratization, sequencing, and state failure in Africa: Lessons from Kenya'. African Affairs 108(430), January.

Brown, S with C L Sriram. 2012. 'The Big Fish Won't Fry Themselves: Criminal Accountability for Post-Election Violence in Kenya'. African Affairs 111(443). Carson, J. 2013. 'Briefing on the Upcoming Kenyan Elections', Africa Regional Media Hub. Available at: janakcommunicationsupdates.blogspot. com/2013/02/uproar-in-kenya-over-us-johnnie-carsons.html

County Weekly, The. 2013. 'How MPs shot down Uhuru, Mudavadi pact', January. Daily Nation. 2009. 'Kenya: ODM Says Will Back Kenya Tribunal Bill', 15 August. Daily Nation. 2011. 'KKK alliance draws more criticism', 24 January.

Daily Nation. 2011. 'Raila Disowns VP's Diplomatic Offensive Over ICC', 26 January.

Daily Nation. 2012. 'Ida calls for local trial for ICC suspects', 27 January.

Daily Nation. 2012. 'They voted for Hague but are now praying with ICC suspects', 6 February. 
Daily Nation. 2012. 'Raila Denies Role in Uhuru, Ruto ICC Cases', 8 February.

Daily Nation. 2012. 'Ruto links ICC case to State House bid', 7 March.

Daily Nation. 2012. 'British MP says West plotting Raila win', 20 March.

Daily Nation. 2012. 'ICC sets trial dates for Kenya's cases', 9 July.

Daily Nation, 2012. 'Ruto accuses Clinton of meddling', 7 August.

Daily Nation. 2012. 'Secrets of Raila meeting with ex-ODM ally', 12 October.

Daily Nation. 2012. 'Why OP officials want Mudavadi for president', 6 December.

Daily Nation. 2013. 'Kibaki, Raila should be on the ICC list, says Uhuru', 24 January.

Daily Nation.2013. 'Uhuru allays fears of power vacuum over Hague trial',

31 January.

Daily Nation. 2013. 'ICC will not affect my regime, says Uhuru', 31 January.

Daily Nation. 2013. 'France to have only "essential contact" with Jubilee leaders',

8 February.

Daily Nation. 2013. 'Kenya asks UN to end trial of Uhuru, Ruto', 9 May.

Daily Nation. 2013. 'President Kenyatta promises to cooperate with ICC', 14 May

Daily Nation. 2013. 'African leaders back plea to halt ICC trial', 27 May.

Daily Nation. 2013. 'ICC sets Ruto, Sang trial date for September 10', 3 June.

East African, The. 2013. 'Kenya's quest to end cases at The Hague enters crucial stage', 25-31 May.

Economist, The. 'Public opinion in Kenya: Politics and justice', 10 October.

Essoungou, A-M. 2011. 'African elections: works in progress: Trends are encouraging, but some polls still fall short'. Africa Renewal. Available at: www.un.org / africarenewal / magazine / august-2011 / african-electionsworks-progress.

Hard Talk Kenya. 2012. 'Telling It Like It Is: "Raila Odinga behind the ICC Conspiracy!" - Rift Valley MPs', 4 March. Available at: hardtalkkenya. wordpress.com/2012/03/14/ raila-odinga-behind-the-icc-conspiracy-riftvalley-mps /

Human Rights Watch. 2008. 'Ballots to Bullets: Organized Political Violence and Kenya's Crisis of Governance'. New York: Human Rights Watch.

Ictville.com. 2013. 'The Tyranny of Numbers (Hypothetically); Mutahi Ngunyi Predicts a Jubilee Alliance Win'. Available at: ictville.com/2013 / 02 / videothe-tyranny-of-numbers-hypothetically-mutahi-ngunyi-predicts-a-jubileealliance-win/

International Commission of Jurists-Kenya Section. 2010. 'ICJ Kenya Position Paper on the Crime of Aggression and Articles 8 \& Article 124 of the Rome Statute and the Stocktaking issues at the ICC Review Conference'. Kampala, Uganda, 31 May-11 June.

International Crisis Group. 2012. 'Kenya: Impact of the ICC Proceedings'. Africa Briefing, 9 January.

International Crisis Group. 2013a. 'Kenya's 2013 Elections'. Africa Report 197, 17 January. 
International Crisis Group. 2013b. 'Kenya after the Elections'. Africa Briefing 54, 15 May.

IPSOS-Synovate. 2011. SPEC Barometer Release, 15 April.

IPSOS-Synovate. 2012. SPEC Barometer, 1 May.

IPSOS-Synovate. 2013a. SPEC Barometer, 24 February.

IPSOS-Synovate. 2013b. Post-Election Analysis, 19 March.

K-24 News. 2013. 'Kabando: Jubilee will win on first round', 23 January. Available at: www.news24.co.ke/MyNews24/Kabando-Jubilee-will-win-in-firstround-20130129

Kagwanja, P. 2009. 'Courting genocide: Populism, ethno-nationalism and the informalisation of violence in Kenya's 2008 post-election crisis'. Journal of Contemporary African Studies 27(3), July.

Kanyinga, K, D Okello \& A Akech. 2010. 'Contradictions of Transition to Democracy in Fragmented Societies: The Kenya 2007 General Elections in Perspective'. In K Kanyinga \& D Okello (eds). Tensions and Reversals in Democratic Transitions: The Kenya 2007 General Elections. Nairobi: Society for International Development and Institute for Development Studies, University of Nairobi. Kenya Daily Post, The. 2012. 'Uhuru and Ruto to step down for Mudavadi and Kosgey', 6 December. Available at: www.kenyan-post.com/2012/12/uhuruand-ruto-to-step-down-for.html.

Kenya Law Reports. 2013. Petition No 552 of 2012, 19 March. Available at: www. kenyalaw.org/newsletter1/Issue072013.php

Kenya National Commission of Human Rights. 2008. 'On the Brink of the Precipice:

AHuman Rights Account of Kenya's Post-2007 Election Violence', 15 August. Kipkorir, D. 2013. 'African leaders back plea to halt ICC trial', Daily Nation $27 \mathrm{May}^{\prime}$. Kipkorir, D. 2013. 'In Yoweri Museveni Africa has a false prophet on ICC and justice'. Sunday Standard 2 June.

Lindenmayer, E \& J L Kaye. 2009. 'A Choice for Peace?: The Story of Forty-One Days of Mediation in Kenya'. New York: International Peace Institute, March. Maina, W. 2013a.' Investigating Ngunyi's Tyranny of Numbers', The Star, 26 February.

Maina, W. 2013b. 'Kenyans Don't Always Vote Tribally'. AFRICOG, 25 February. Maina, W. 2013c. 'Five key reasons Kenya's Supreme Court failed crucial election petition test'. The East African 20-26 April.

Mghanga, M. 2010. Usipoziba Ufa Utajenga Ukuta: Land, elections and conflicts in Kenya's Coast Province. Nairobi: Heinrich Boll Foundation.

Miguna, M. 2012. Peeling Back the Mask: A Quest for Justice in Kenya. Gilgamesh Africa.

Mue, N. 2013. 'Addressing the Elephant in the Room: Implications of an Uhuru/ Ruto Presidency for Kenya in light of the ICC trials'. Seminar Presentation, 'Kenya's 2013 Elections - Issues, Actors and Scenarios', Institute for Strategic Studies, Nairobi, 28 February. 
Mueller, S. 2008. 'The Political Economy of Kenya's Crisis'. Journal of Eastern African Studies 2(2), July.

Muigai, G. 2004. 'Jomo Kenyatta \& the Rise of the Ethno-Nationalist State in Kenya'. In B Berman, D Eyoh \& W Kymlicka (eds). Ethnicity \& Democracy in Africa. London: James Currey.

Muluka, B. 2010. 'Welcome, Moreno-Ocampo, to slay the dragon of impunity coiling around us'. Saturday Standard 3 April.

Muluka, B. 2011. 'Was the Rift Valley ever behind a Raila presidency?'. Nairobi Law Monthly 2(4), April.

Muluka, B. 2013. 'Sins that killed a campaign strategy'. Nairobi Law Monthly 4(4), May.

Mutua, M. 2012. 'Why are Kenyans so easily manipulated by tribal elites?'. Sunday Nation, 28 October.

Mutua, M. 2013. 'Is there too much Ruto at President Kenyatta's side?', Sunday Nation, 14 April.

Mwagiru, M. 2008. The Water's Edge: Medication of Violent Electoral Conflict in Kenya. Nairobi: Institute of Diplomacy and International Studies.

Nairobi Law Monthly, The. 2011. 'The ICC elections', April.

New York Times. 2013. 'Leader of Vote Count in Kenya Faces U.S. With Tough Choices', 7 March.

Obama, B. 2013. 'President Obama's Message to the People of Kenya', The White House, 5 February. Available at: www.whitehouse.gov/ photos-and-video/ video/2013/02/05/ president-obama-s-message-people-kenya.

Oloo, A. 2010. ‘Party Mobilization and Membership: Old and New Identities in Kenyan Politics'. In K Kanyinga \& D Okello (eds). Tensions and Reversals in Democratic Transitions: The Kenya 2007 General Elections. Nairobi: Society for International Development/Institute of Development Studies.

Opanga, K. 2012. 'Alliances are not about peace, they are about power'. Sunday Nation, 21 October.

Orange Democratic Movement. 2011. 'Petition To The Members Of UN Security Council Regarding The Kenyan Cases At The ICC', 11 March.

Raila Odinga Secretariat. 2012. 'Press Release on the Coming General Election', 12 March.

Republic of Kenya. 2008. Report of the Commission of Inquiry into Post-Election Violence. Nairobi: Government Printer.

Reuters. 2010. 'INTERVIEW-ICC: Prosecutor Targets Up to Six Kenyans', 12 May. Reuters / AFP. 2013. 'Fears for Witness Protection as Transfer of ICC Kenya Trial Mooted', 4 June. Available at: allafrica.com/stories / 201306050519.html?aa_ source $=$ slideout.

South Consulting. 2011. 'Progress in Implementation of the Constitution and other reforms'. The Kenya National Dialogue and Reconciliation (KNDR) Monitoring Project Review Report, October. 
Southall, R \& H Melber (eds). 2006. 'Introduction'. In Legacies of Power: Leadership Change and Former Presidents in African Politics. Cape Town/Uppsala: Human Sciences Research Council/Nordikafrika Institut.

Standard, The. 2011. 'Shuttle diplomacy over ICC cases escalates', 19 February.

Standard, The. 2012. 'Show of solidarity as ICC suspects attend prayer meeting in Eldoret', 28 January.

Standard, The. 2012.' Raila Odinga Secretariat Press Release on the Coming General Election', 12 March.

Standard, The. 2012. 'Conspiracy against The Hague?', 28 March.

Standard, The. 2012. 'Bensouda jets in as Uhuru, Ruto intensify campaigns', 21 October.

Standard, The. 2012. 'Bensouda comes face to face with IDPs' misery, 26 October.

Standard, The. 2013. 'UK to avoid contact with ICC suspects', 16 January.

Standard, The. 2013. 'Jubilee hails Obama's call, exudes confidence', 7 February.

Standard, The. 2013. 'CORD warns against electing Uhuru, Ruto', 11 February.

Star, The. 2011. 'Raila woos back Kalenjin', 4 June.

Star, The. 2012. 'What Raila promised Ruto', 5 May.

Star, The. 2012. 'An investigation by parliament's Defense and Foreign Relations committee eventually determined the documents were fake; "ICC 'dossier" not authentic, committee says', 14 December.

Star, The. 2012. 'Uhuru agreed to step down and back me-Mudavadi', 18 December. Star, The. 2013. 'West's dilemma over Uhuru, Ruto', 16 February.

Star, The. 2013. 'TNA, URP betrayed me - VP', 3 December.

Sunday Nation. 2012. 'How ICC and Raila created "coalition of the accused"', 2 December.

Sunday Standard. 2012. 'Uhuru, Ruto allies hit out at UK minister', 5 February. Sunday Standard. 2012. 'Kalonzo, Ruto to form coalition for easy win', 19 August. Sunday Standard. 2013. 'When ICC, land cases became a major headache for Uhuru and Ruto', 26 May.

Tanui, K. 2011. 'In ICC prayers, be careful what you wish for'. The Standard, 4 August.

Throup, D. 2012. 'Reading the Tea Leaves on the Kenyan Elections: Patterns of Violence and Political Alliances'. Centre for Strategic and International Studies, 16 November. Available at: csis.org/publication/ reading-tea-leaveskenyan-elections-patterns-violence-and-political-alliances.

TOPIX. 2011. 'ICC complicates Raila's 2012 Kenya presidential bid', 23 April. Available at: www.topix.com/forum/world/kenya/TLLOFIFT4RSJ3ASHD

Van de Walle, N. 2006. ‘Tipping games: When do opposition parties Coalesce?'. In ASchedler (ed). Electoral Authoritarianism: The Dynamics of Unfree Competition. Boulder: Lynne Rienner.

Wanjala, D. 2013. 'Big race shapes up'. The Nairobi Law Monthly 4(2), February.

Waweru, D. 2012. 'The Rise of the 'UhuRuto'. African Arguments, 5 December. 
Available at: africanarguments.org/2012/12/05/kenya-the-rise-of-the$\%$ E2\%80\%98uhuruto\%E2\%80\%99-by-daniel-waweru/

Weekly Citizen. 2010. 'Raila's swift reaction to Ocampo bound to raise queries'.

Wikipedia. 2013. 'Kenya Presidential Election'. Available at: en.wikipedia.org/ wiki/Kenyan_presidential_election,_2013\#Opinion_polling.

Wolf, T. 2013. 'Opinion Polls: Factors that might influence outcome'. Sunday Nation, 24 February.

Wrong, M. 2013. 'Indictee for President!', International Herald Tribune - Latitude, March 11. 